\title{
Microbiological stability of homeopathic medicines using purified water as vehicle.
}

\author{
Virgínia Tereza Cegalla, Amarilys de Toledo Cesar \\ HN Homeopatia e Naturais, São Paulo, Brazil
}

\begin{abstract}
Background: Homeopathic medicines are prepared in homeopathic pharmacies. This leads to freedom of prescription but requires more knowledge of the clinicians to achieve the best results. Preparations made of purified water receive a validity of 24 hours, but there are prescriptions for up to 30 days. This contradiction raises tensions among physicians, pharmacists and patients.
\end{abstract}

Aims: to evaluate the increase in microbiological contamination in homeopathic medicines using purified water as vehicle compared with the microbiological stability of purified water. Contribute to the quality of homeopathic medicine and treatment.

Methodology: daily microbiological analysis for one week to assess the growth of heterotrophic bacteria, Pseudomonas, yeasts and molds. The reference used was the USP 32/NF 27 and the Brazilian Pharmacopoeia 5th edition.

Results: there was a higher growth of microorganisms on the medicine, compared with purified water. From the 2nd day on, this growth has been beyond the legal limits.

Discussion: medicines for oral use are not sterile preparations, but they must remain stable during its shelf life. Our results indicate that contamination occurs from the earliest days of use. This shows the need to change the prescription in relation of the vehicle, to ensure hygiene and avoid potential contamination of the patient. It is necessary to prevent conflict of information between pharmacists and patients, and the contradiction of the doctor's advice, besides the potential risk of responsibility to be attributed to the pharmacy. It is necessary to promote a discussion between pharmacists and clinicians, to spread this information for those that prescribe.

Conclusion: there was an increased of microbiological contamination of the medicines dispensed in purified water, which harms the quality of homeopathic medicine and homeopathic treatment.

Key words: microbiology, homeopathic medicine, purified water. 


\section{Estabilidade microbiológica de medicamentos homeopáticos veiculados em água purificada}

\section{RESUMO}

Introdução: Medicamentos homeopáticos são manipulados em farmácias com manipulação homeopática. Isto leva a liberdade de prescrição, porém exige mais conhecimento por parte dos clínicos, para atingir os melhores resultados. Preparações em água purificada recebem validade de 24 horas, mas existem prescrições para tomar o medicamento durante 30 dias. Esta contradição gera tensões entre médicos, farmacêuticos e pacientes.

Objetivos: avaliar o aumento da carga microbiana em medicamentos homeopáticos veiculados em água purificada, em comparação com a estabilidade microbiológica da água purificada. Contribuir com a qualidade do medicamento e do tratamento homeopático.

Metodologia: análises microbiológicas diárias durante uma semana para avaliação do incremento de bactérias heterotróficas, Pseudomonas, bolores e leveduras. A referência utilizada foi a USP 32/NF 27 e a Farmacopeia Brasileira $5^{\mathrm{a}}$ edição.

Resultados: houve um maior crescimento de microorganismos no medicamento, quando comparado com a água purificada. Este crescimento foi além dos limites permitidos na legislação a partir do $2^{\circ}$ dia.

Discussão: os medicamentos para uso oral não são estéreis, porém devem manter-se estáveis durante seu prazo de validade. Nossos resultados indicam que a contaminação ocorre desde os primeiros dias de uso. Isto mostra a necessidade de alterar a prescrição médica em relação ao veículo, para garantir a higiene e evitar a potencial contaminação do paciente. É necessário prevenir o conflito de informações entre farmacêuticos e pacientes, e a contradição da indicação do médico, além de potencial risco da responsabilidade de medicamento contaminado recair sobre a farmácia. É necessário promover uma discussão entre farmacêuticos e clínicos, para que estas informações sejam divulgadas para a classe prescritora.

Conclusões: houve aumento da carga microbiana dos medicamentos dispensados em água purificada, o que prejudica a qualidade do medicamento homeopático e do tratamento homeopático.

Palavras-chave: microbiologia; medicamento homeopático; água purificada.

\section{(c)) EY-NC-ND Licensed to GIRI}

Support: The work was supported by the group HN Cristiano, laboratory and pharmacy.

Conflict of interest: authors declare there is no conflict of interest, once they work producing Mother Tincture and dynamizations in an industrial laboratory, and not in a pharmacy.

Correspondence author: Name, Virginia.cegalla@hncristiano.com.br, http://www.hncristiano.com.br

How to cite this article: Cegalla VT, Cesar AT. Microbiological stability of homeopathic medicines using purified water as vehicle. Int J High Dilution Res [online]. 2011 [cited YYYY Month dd]; 10(36): 222-223. Proceedings of the XXV GIRI Symposium and VIII CBFH; 2011 Sep 04-07; Foz do Iguaçu (Brazil). GIRI and ABFH; 2011; Available from: http://www.feg.unesp.br/ ojs/index.php/ijhdr/article/view/491/504 